\title{
Bimbingan Teknis Aplikasi Portal Rumah Belajar pada Praktik Pembelajaran Daring di Masa Pandemi Covid-19
}

\author{
Zahra Khusnul Latifah, Irma Inesia Sri Utami \\ Universitas Djuanda \\ Email: zahra.khusnul.latifah@unida.ac.id,irma.inesia@unida.ac.id
}

Application

\begin{tabular}{l}
\multicolumn{1}{c}{ Article Info } \\
\hline Submitted: 26 January 2021 \\
Revised: 27 February 2021 \\
Accepted: 16 April 2021 \\
Published: 21 April 2021 \\
Keywords: Portal Rumah \\
Belajar, Online Learning, \\
Application
\end{tabular}

\section{Article Info}

Submitted: 26 January 2021

Revised: 27 February 2021

Accepted: 16 April 2021

Keywords: Portal Rumah Belajar, Online Learning,

\begin{abstract}
The Portal Rumah Belajar is an internet-based application launched by the Ministry of Education and Culture to facilitate the creation of virtual classrooms for online teaching practices. The use of these applications is relevant to learning during a pandemic that implements the Distance Learning (PJJ) system. In this regard, the Portal Rumah Belajar application is one of the applications recommended by the Ministry of Education and Culture for teachers in carrying out teaching and learning activities during the pandemic. However, the facts in the field show that the use of the Portal Rumah Belajar is still low when compared to the use of WhatsApp Group. The use of WhatsApp Group as a means of online learning has limitations in facilitating active online classrooms so that learning activities tend to be monotonous. Besides, it is difficult for teachers to manage to learn. The situation analysis of these problems is the background for the implementation of service activities in the form of technical guidance for the Portal Rumah Belajar application in online learning during the pandemic. Based on this, this service activity aims to facilitate teachers to understand, practice, and be able to optimize online learning activities during the pandemic through the use of the Portal Rumah Belajar application. The method of community service activities is carried out in the form of a National Webinar in three activity sessions. Concerning the achievement and success of each session, the post-test technique is used to determine the participants' achievements and successes in each webinar session. The results of the implementation of this service activity show that the participants, namely teachers from various regions in Indonesia, including West Java, Belitung, and Central Java, gained an understanding both in the form of theory and practice regarding the use of the Portal Rumah Belajar application along with its main and supporting features to support the optimization of learning activities with the system. online during a pandemic. In general, it can be concluded that the implementation of this mentoring activity was able to increase the understanding and enthusiasm of the teachers participating in the National Webinar activities to carry out quality online learning in their respective educational units.
\end{abstract}


Kata kunci: Portal Rumah Belajar, Online Learning, Aplikasi

\begin{abstract}
Abstrak
Portal Rumah Belajar merupakan aplikasi berbasis internet yang diluncurkan oleh Kemdikbud untuk memfasilitasi terciptanya ruang kelas maya pada praktik pengajaran dalam jaringan (daring). Penggunaan aplikasi tersebut sesungguhnya relevan dengan pembelajaran di masa pandemi yang menerapkan sistem Pembelajaran Jarak Jauh (PJJ). Berkaitan dengan hal tersebut aplikasi Portal Rumah Belajar menjadi salah satu aplikasi yang direkomendasikan oleh Kemdikbud pada para guru dalam melaksanakan kegiatan belajar mengajarnya di masa pandemi. Namun fakta di lapangan menunjukkan bahwa pemanfaatan Portal Rumah Belajar terbilang masih rendah bila dibandingkan dengan penggunaan WhatsApp Group. Penggunaan WhatsApp Group sebagai sarana pembelajaran daring sesungguhnya memiliki keterbatasan dalam memfasilitasi ruang kelas online yang aktif sehingga kegiatan pembelajaran cenderung monoton. Selain itu, pengelolaan pembelajaran pun sulit dilakukan oleh guru. Analisis situasi terhadap permasalahan tersebut melatarbelakangi pelaksanaan kegiatan pengabdian berupa bimbingan teknis aplikasi Portal Rumah Belajar dalam pembelajaran daring di masa pandemi. Berdasarkan hal tersebut, adanya kegiatan pengabdian ini bertujuan untuk memfasilitasi para guru agar dapat memahami, mempraktikkan dan mampu mengoptimalkan kegiatan pembelajaran daring di masa pandemi melalui pemanfaatan aplikasi Portal Rumah Belajar. Metode kegiatan pengabdian dilaksanakan dalam bentuk kegiatan Webinar Nasional dalam tiga sesi kegiatan. Terkait dengan capaian dan keberhasilan tiap sesi digunakan teknik post tes guna mengetahui bagaimana capaian dan keberhasilan peserta pada tiap sesi webinar. Hasil pelaksanaan kegiatan pengabdian ini menunjukkan bahwa para peserta yakni guru dari berbagai wilayah di Indonesia diantaranya Jawa Barat, Belitung, dan Jawa Tengah memperoleh pemahaman baik berupa teori maupun praktik mengenai pemanfaatan aplikasi Portal Rumah Belajar beserta fitur utama maupun fitur pendukung untuk menunjang optimalisasi kegiatan pembelajaran dengan sistem daring di masa pandemi. Secara umum dapat disimpulkan bahwa pelaksanaan kegiatan pendampingan ini mampu meningkatkan pemahaman dan antusiasme para guru peserta kegiatan Webinar Nasional untuk melaksanakan pembelajaran daring yang berkualitas di satuan pendidikan masing-masing.
\end{abstract}

\section{PENDAHULUAN}

Aplikasi Portal Rumah Belajar pada dasarnya merupakan sarana pendukung pembelajaran daring (dalam jaringan) yang dikelola oleh Kementerian Pendidikan dan Kebudayaan (Kemdikbud). Adanya aplikasi tersebut sesungguhnya sangat relevan digunakan dalam praktik pembelajaran di masa pandemi saat ini. Sebagaimana yang diketahui bahwa adanya pandemi tersebut telah mempengaruhi dan merubah tataran praktik pembelajaran (Putria et al., 2020). Praktik pembelajaran yang sebelumnya dilaksanakan secara tatap muka kini harus dilaksanakan dengan sistem Pembelajaran Jarak Jauh (PJJ) atau yang lebih dikenal dengan sistem dalam jaringan (daring) sebagai tindakan preventif pembentukan klaster baru penyebaran virus Covid-19 di lingkungan sekolah. Pemberlakuan praktik pendidikan dengan sistem daring tersebut pada dasarnya merupakan desain ideal untuk melaksanakan kegiatan pengajaran di 
tengah masa pandemi saat ini (Imania, 2019). Hal ini selaras dengan pernyataan Sofyana \& Abdul (2019) bahwa pembelajaran jarak jauh atau pembelajaran berbasis daring memfasilitasi terlaksananya kegiatan pembelajaran tanpa harus bertatap muka langsung antara guru dan murid. Sehingga penerapan sistem daring pada praktik pembelajaran di masa pandemi dinilai tepat dilaksanakan saat ini. Mengingat bahwa pada sistem PJJ tersebut penggunaan aplikasi penyedia ruang kelas virtual menjadi sesuatu yang vital sehingga peranannya menjadi hal yang tidak dapat dihindarkan. Portal Rumah Belajar sebagai aplikasi belajar online memberikan dan memfasilitasi terciptanya ruang belajar virtual secara optimal bagi guru maupun siswa dalam praktik sistem PJJ.

Adapun fakta di lapangan menunjukkan bahwa para guru dalam melaksanakan pembelajaran daring cenderung menggunakan aplikasi selain Portal Rumah Belajar. Hal ini sebagaimana persentase data pernyataan partisipan pada survei mengenai aplikasi yang digunakan dalam pembelajaran daring menemukan bahwa sebanyak 74,4\% guru melaksanakan pembelajaran daring selama masa pandemi melalui aplikasi WhatsApp. Penggunaan aplikasi WhatsApp untuk menunjang kegiatan belajar online sesungguhnya dinilai praktis dan efisien karena secara umum aplikasi WhatsApp ini dimiliki dan digunakan oleh banyak orang sehingga pengoperasiannya menjadi hal yang telah dikuasai oleh peserta didik maupun guru itu sendiri. Namun disisi lain, penggunaan aplikasi WhatsApp ini memiliki keterbatasan dalam mengelola kegiatan belajar mengajar secara aktif karena hanya menyediakan ruang untuk berdiskusi dengan kapasitas share file yang sangat terbatas (Bhagaskara et al., 2021). Bila kita telaah lebih lanjut, kondisi tersebut sesungguhnya berdampak pada terbatasnya kemampuan guru dalam mengelola dan melaksanakan kegiatan belajar mengajarnya, adapun hal tersebut tentu akan sangat berpengaruh terhadap hasil belajar siswa. Hal ini sebagaimana paparan Saragih \& Ansi (2020) bahwa penggunaan aplikasi WhatsApp dalam pembelajaran daring menyulitkan guru dalam mengelola kegiatan belajar mengajar khususnya dalam melaksanakan evaluasi pembelajaran. Adapun disisi lain, temuan penelitian yang dilakukan oleh Daheri et al., (2020) menemukan bahwa penggunaan aplikasi WhatsApp dinilai kurang efektif digunakan dalam pembelajaran daring, hal ini didasari oleh beberapa kelemahan aplikasi tersebut dalam memfasilitasi kegiatan pembelajaran yaitu adanya keterbatasan dalam menciptakan pembelajaran yang aktif dan interaktif serta rendahnya pengembangan aspek afektif dan psikomotorik dalam kegiatan belajar mengajar.

Berdasarkan analisis situasi di atas, pembiaran terhadap praktik pengajaran daring dengan aplikasi tersebut dikhawatirkan akan menurunkan kualitas pembelajaran daring di masa pandemi sedangkan melaksanakan kegiatan belajar mengajar yang optimal dan berkualitas merupakan tanggung jawab guru sebagai fasilitator kegiatan belajar mengajar, adapun memperoleh pengalaman belajar yang berkualitas, efektif, dan efisien merupakan hak peserta didik yang harus dipenuhi. Oleh sebab itu, peningkatan kualitas praktik pengajaran daring ini menjadi hal yang harus dilaksanakan sedini mungkin. Adapun salah satu langkah yang dapat dilakukan oleh para guru adalah dengan menguasai aplikasi berbasis teknologi internet yang dapat memudahkan guru dalam mengelola dan melaksanakan kegiatan belajar daring antara guru dan siswa secara efektif (Rigianti, 2020). Penggunaan aplikasi berbasis internet yang tepat guna tentunya akan meningkatkan capaian praktik pembelajaran itu sendiri. Berkaitan dengan hal tersebut, Kemdikbud sesungguhnya telah lama menyadari kebutuhan aplikasi berbasis internet dalam pemutakhiran praktik pengajaran yang sebelumnya konvensional menuju pengajaran berbasis sistem PJJ di era abad 21 bahkan sebelum pandemi Covid-19 ini melanda (Sulistiyani, 2018). Adapun aplikasi berbasis internet tersebut adalah Portal Rumah Belajar yang pada dasarnya merupakan sebuah platform yang memfasilitasi kegiatan pembelajaran daring melalui berbagai fitur yang dapat dimanfaatkan oleh guru dan siswa serta sekolah sebagai penyelenggara. Supandri (2018) menyatakan bahwa Portal Rumah Belajar merupakan program Kemdikbud yang dikembangkan oleh Pusat Data dan Teknologi Informasi (Pusdatin). Portal Rumah Belajar sendiri dapat diakses melalui alamat https:// belajar.kemdikbud.go.id/ oleh seluruh warga 
negara Indonesia. Namun untuk penggunaan mendalam dari tiap fiturnya, pengguna membutuhkan akses resmi yang dapat diperoleh secara kolektif melalui sekolah sebagai penyelenggara yang terlebih dahulu harus mendaftarkan diri sesuai dengan prosedur yang ditetapkan oleh Pusdatin. Di sisi lain Portal Rumah Belajar dapat disebut pula sebagai media online yang menyediakan ruang belajar interaktif antara guru dan siswa. Melalui aplikasi Portal Rumah Belajar, baik guru maupun siswa dapat berinteraksi langsung dalam kelas maya dan mengakses berbagai fitur sumber belajar yang dapat meningkatkan efektivitas kegiatan belajar dengan sistem daring (Chabibie \& Hakim, 2016). Selain itu Yanti, et al., (2020) menyatakan bahwa Portal Rumah Belajar sebagai sebuah terobosan dalam sistem pembelajaran di Indonesia yang menyediakan sistem tata kelola pembelajaran berbasis virtual. Melalui Portal Rumah Belajar, guru berperan maksimal sebagai fasilitator kegiatan belajar siswa dengan tetap mendorong siswa untuk mengeksplor wawasannya melalui pemanfaatan berbagai fitur yang tersedia dalam Portal Rumah Belajar. Sejalan dengan paparan tersebut Warsita (2019) berdasarkan hasil penelitiannya menemukan bahwa penggunaan aplikasi Portal Rumah Belajar terbukti efektif meningkatkan kualitas pembelajaran dengan sistem online sehingga Portal Rumah Belajar dinilai sebagai sarana yang dapat digunakan untuk meningkatkan optimalisasi pembelajaran dengan sistem daring. Memperkuat temuan penelitian tersebut, Ferismayanti (2019) mengemukakan bahwa Portal Rumah Belajar relevan digunakan dalam kegiatan pembelajaran daring karena aplikasi tersebut mengusung konsep model pembelajaran hypermedia sehingga mampu menciptakan ruang kelas online yang memfasilitasi terjadinya komunikasi interaktif antara guru dengan siswa. Oleh karena itu, aplikasi Portal Rumah Belajar dinilai layak digunakan sebagai sarana pembelajaran daring yang berorientasi pada peningkatan kualitas praktik pembelajaran. Sehingga tidak heran bila Kemdikbud sendiri merekomendasikan pemanfaatan Portal Rumah Belajar dalam pembelajaran daring di masa pandemi.

Berdasarkan paparan di atas, jelas bahwa adanya aplikasi Portal Rumah Belajar Kemdikbud ini sesungguhnya merupakan jawaban yang menjawab kebutuhan guru mengenai aplikasi berbasis internet yang dapat digunakan untuk meningkatkan efektivitas pembelajaran daring di masa pandemi ini. Namun sayangnya ditengah kebijakan daring saat ini pengguna aplikasi Portal Rumah Belajar masih terbilang rendah bila dibandingkan dengan aplikasi WhatsApp. Hal ini sebagaimana temuan penelitian Assidiqi \& Sumarni (2020) bahwa aplikasi yang sering dan paling banyak digunakan dalam praktik pembelajaran daring di masa pandemi ini adalah WhatsApp Group, Google Classroom, dan Zoom Cloud Meeting. Adapun di sisi lain, Salsabila, et al., (2020) mengemukakan bahwa teknologi media pembelajaran berbasis online yang paling banyak digunakan pada pembelajaran di masa pandemi ini yaitu WhatsApp Group. Berdasarkan hal tersebut dapat diketahui bahwa penggunaan aplikasi Portal Rumah Belajar Kemdikbud sebagai ruang kelas virtual masih kurang diminati para guru dalam melaksanakan pembelajaran daring.

Berangkat dari analisis situasi di atas, diperlukan sebuah kegiatan bimbingan teknis yang memfasilitasi para guru untuk memahami, menggunakan dan mengoptimalkan aplikasi Portal Rumah Belajar dalam praktik pembelajaran daring. Kegiatan bimbingan teknis tersebut pada praktiknya tidak hanya menjelaskan konsep dasar aplikasi Portal Rumah Belajar saja tetapi para guru pun didorong untuk mampu memanfaatkan aplikasi Portal Rumah Belajar dalam pembelajaran berbasis sistem online. Oleh karena itu, dilaksanakan kegiatan bimbingan teknis dalam bentuk webinar nasional dengan tema "Pendampingan Pembelajaran Daring berbasis Aplikasi Portal Belajar" yang terbagi dalam tiga sesi. Pada praktiknya pelaksanaan webinar tersebut memberikan pelatihan terpadu antara teori dan praktik secara berkesinambungan guna mengoptimalkan pemahaman, penggunaan, dan optimalisasi aplikasi Portal Rumah Belajar. Berdasarkan hal tersebut adanya bimbingan teknis aplikasi Portal Rumah Belajar pada pembelajaran daring di masa pandemi ini bertujuan untuk memfasilitasi para guru agar mampu meningkatkan kualitas pembelajaran daring di masa pandemi melalui penggunaan aplikasi Portal Rumah Belajar Kemdikbud di satuan pendidikannya masing-masing. 
Adapun manfaat yang diperoleh dari kegiatan pengabdian ini yakni penguasaan baik teori maupun praktik aplikasi Portal Rumah Belajar sebagai media penunjang pembelajaran daring serta tersosialisasikannya program Kemdikbud dalam mendorong penggunaan Portal Rumah Belajar dalam pembelajaran daring sebagai langkah nyata menuju pengajaran mutakhir yang relevan dengan kebutuhan zaman.

\section{METODE}

Sebagaimana yang telah dipaparkan sebelumnya di atas bahwa untuk memecahkan permasalahan dalam pembelajaran daring di masa pandemi maka solusi yang diajukan adalah melaksanakan bimbingan teknis Aplikasi Portal Rumah Belajar pada pembelajaran daring yang dilaksanakan dalam bentuk kegiatan webinar nasional. Hal ini berdasarkan pertimbangan bahwa kegiatan webinar dinilai efektif untuk menjembatani jarak antara peserta pendampingan dengan instruktur tanpa mengesampingkan efektivitas kegiatan pelatihan yang menjadi tujuan utama dalam kegiatan tersebut (Gegenfurtner et al., 2020). Adapun sasaran dari pelaksanaan webinar nasional tersebut yakni para guru di setiap jenjang pendidikan dari berbagai wilayah di Indonesia. Pada praktiknya pelaksanaan webinar ini diikuti oleh 301 peserta yang didominasi oleh partisipan yang berasal dari provinsi Jawa Barat yakni sebanyak 114 peserta. Berikut disajikan diagram jumlah partisipan berdasarkan provinsi asalnya:
Guna mengoptimalkan capaian dari adanya kegiatan pengabdian ini, maka kegiatan webinar dilaksanakan secara paralel dalam bentuk rangkaian kegiatan selama 3 minggu berturutturut. Desain dari kegiatan pengabdian yang direalisasikan dalam webinar ini mengadopsi tiga tahap optimalisasi webinar yang dikemukakan oleh Lieser et al., (2018) yakni melaksanakan penilaian kebutuhan, mengumpulkan data tentang persepsi pelaksanaan webinar, dan evaluasi berdasarkan hasil analisis dua tahap sebelumnya. Pada pengabdian ini, ketiga tahapan tersebut kemudian dijabarkan dalam beberapa langkah sebagaimana yang tercantum pada Gambar 2.

Berdasarkan Gambar 2 dapat diketahui runtutan langkah-langkah yang digunakan dalam melaksanakan kegiatan pendampingan pembelajaran daring berbasis aplikasi Portal Rumah Belajar ini. Berikut uraian dari langkahlangkah tersebut:

a. Pengamatan awal

Pengamatan awal pada dasarnya merupakan langkah di mana tim pengabdian melakukan pengamatan awal terhadap permasalahan pendidikan yang tengah dihadapi oleh para guru di lapangan. Kegiatan pada pengamatan awal ini meliputi analisis kondisi di lapangan serta analisis literatur yang dilaksanakan untuk memperkuat temuan permasalahan yang kemudian melandasi pelaksanaan kegiatan pengabdian ini.
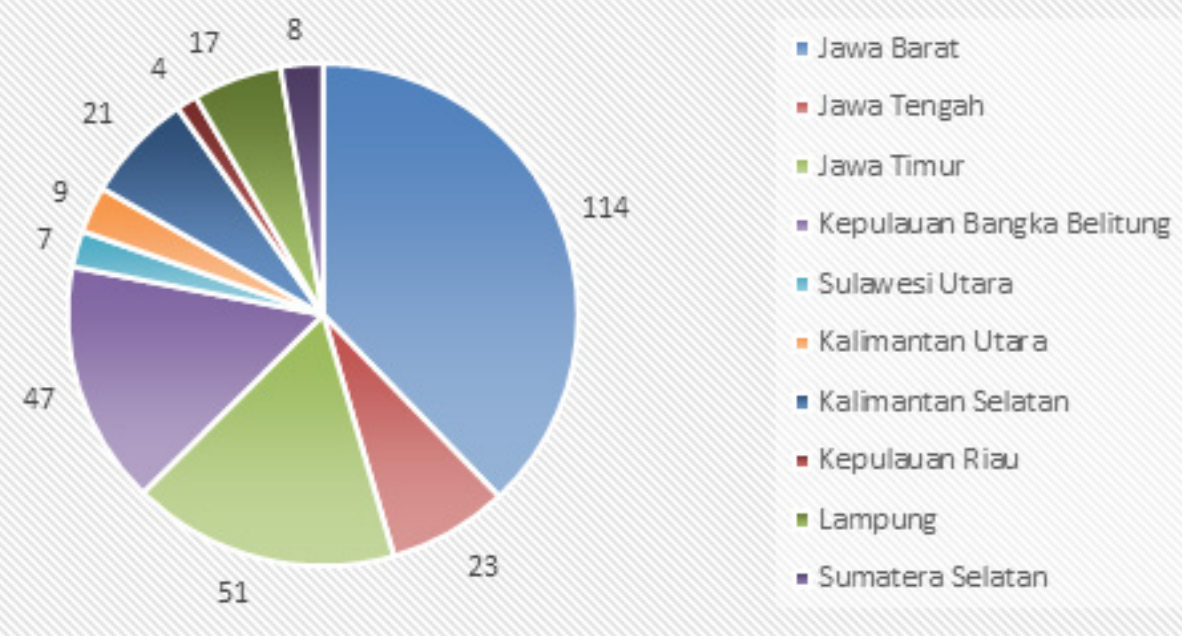

Gambar 1. Diagram Partisipan berdasarkan Provinsi 


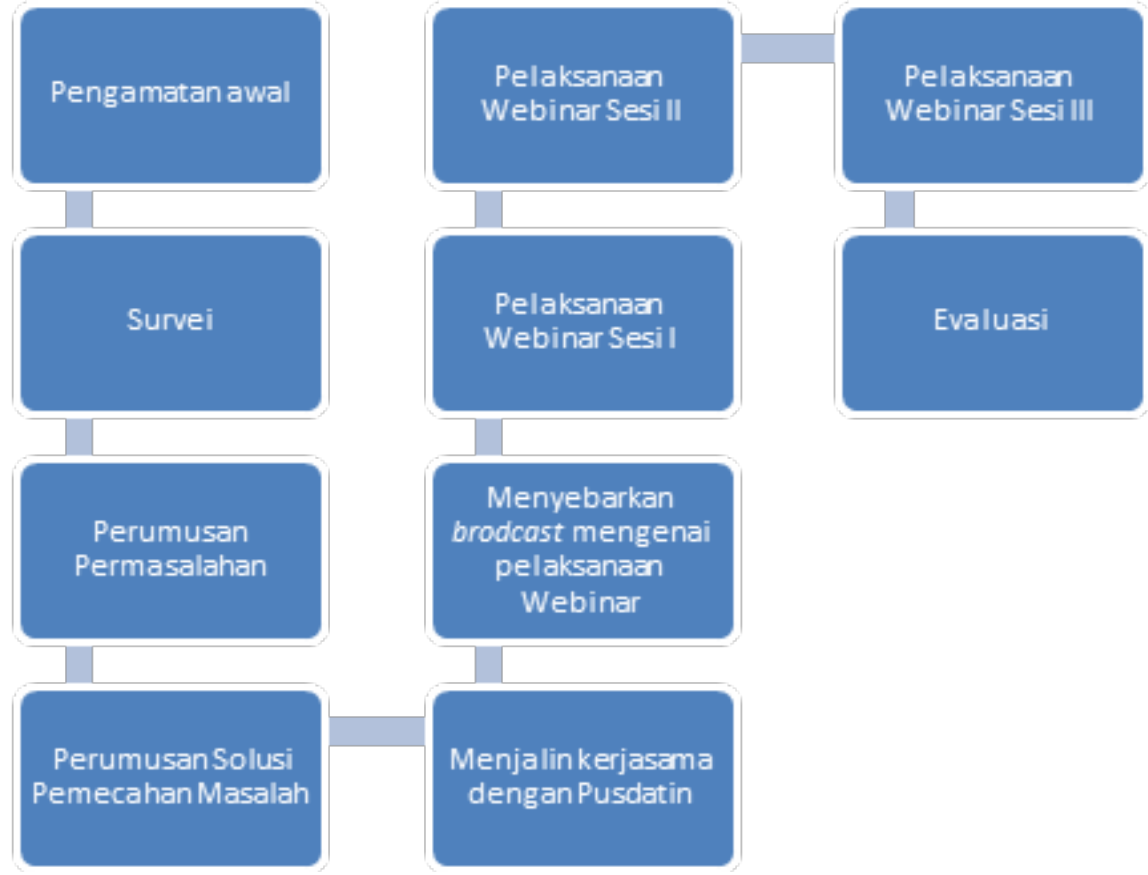

Gambar 2. Metode Pelaksanaan Kegiatan Pendampingan

b. Survei

Berdasarkan temuan permasalahan di lapangan, tim pengabdian mengadakan survei terhadap guru dari berbagai jenjang studi di berbagai wilayah Indonesia mengenai aplikasi yang digunakan dalam pembelajaran daring di masa pandemi.

c. Perumusan Masalah

Berdasarkan analisis terhadap hasil survei yang telah dilaksanakan, maka tim pengabdian melakukan perumusan pokok masalah yang dihadapi para guru dalam melaksanakan pembelajaran daring di masa pandemi berkaitan dengan aplikasi yang digunakan

d. Perumusan Solusi Pemecahan Masalah Setelah masalah dikerucutkan, selanjutnya tim pengabdian melakukan perumusan solusi pemecahan masalah yang tepat guna untuk menanggulangi permasalahan tersebut. Adapun solusi pemecahan masalah yang diajukan adalah melaksanakan kegiatan pendampingan pembelajaran daring berbasis aplikasi Portal Rumah Belajar yang dilaksanakan melalui rangkaian kegiatan Webinar Nasional yang dapat sifatnya terbuka untuk seluruh guru di wilayah Indonesia dan dari berbagai jenjang pendidikan. e. Menjalin kerjasama dengan Pusdatin

Pada praktiknya dalam melaksanakan kegiatan pendampingan ini, tim peneliti berkolaborasi dengan FKIP Universitas Djuanda untuk menjalin kerjasama dengan Pusdatin Kemendikbud. Melalui kerjasama yang terjalin antara tim peneliti, FKIP Universitas Djuanda dan tim ahli dari Pusdatin kegiatan pendampingan pembelajaran daring berbasis aplikasi Portal Rumah Belajar didesain sedemikian rupa agar mampu memfasilitasi dengan baik para peserta yang mengikuti kegiatan pendampingan tersebut.

f. Menyebarkan broadcast mengenai pelaksanaan Webinar Nasional

Penyebaran broadcast menjadi bagian yang penting dalam kegiatan webinar guna menjangkau dan menarik minat banyak peserta dari berbagai wilayah di Indonesia. Broadcast itu sendiri disebarkan 2 minggu sebelum kegiatan Webinar Nasional ini dilaksanakan, oleh karena itu pendaftaran peserta webinar telah masuk sejak broadcast disebarluaskan. Berikut flyer kegiatan pendampingan dalam broadcast yang disebarkan melalui media sosial: 

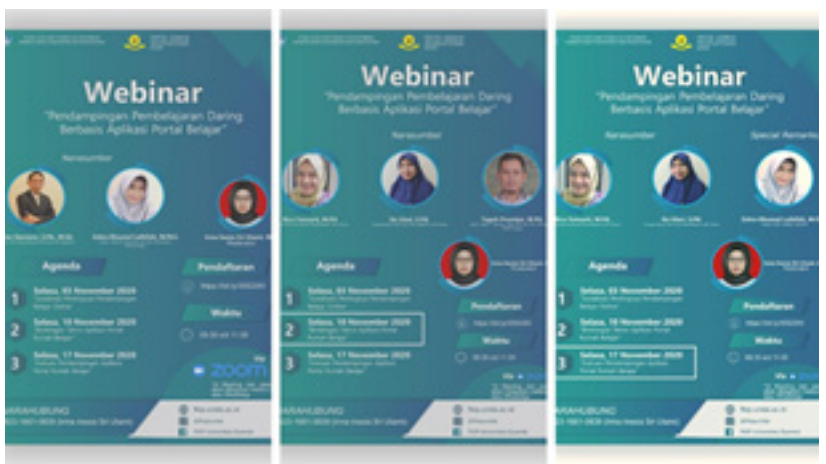

W E B I N A R

PENDAMPINGAN PEMBELAJARAN DARING BERBASIS APLIKASI PORTAL BELAJAR

Gambar 3. Flyer Webinar Pendampingan Pembelajaran Daring Berbasis Aplikasi Portal Belajar

g. Pelaksanaan Webinar Sesi I

Webinar pendampingan pembelajaran daring berbasis aplikasi Portal Belajar yang pertama dilaksanakan pada hari Selasa tanggal 3 November 2020 dengan mengusung sub tema "Sosialisasi Pentingnya Pendampingan Belajar Online" yang dilaksanakan pukul 09.30 sampai 11.00 WIB melalui aplikasi Zoom. Pemateri pada Webinar sesi 1 ini yaitu Ibu Zahra Khusnul Lathifah, M.Pd.I. dari FKIP Universitas Djuanda dan Bapak Irfan Steviano, S.Pd., M.Ed. dari Pusdatin. webinar sesi I dengan sub-tema tersebut memfasilitasipara pesertauntukmemahami pentingnya praktik pendampingan dalam melaksanakan pembelajaran online yang efektif melalui penggunaan berbagai aplikasi berbasis internet.

h. Pelaksanaan Webinar Sesi II

Webinar pendampingan pembelajaran daring berbasis aplikasi Portal Belajar sesi ke II dilaksanakan pada hari Selasa tanggal 10 November 2020 dengan subtema "Bimbingan Teknis Aplikasi Portal Rumah Belajar" dengan pemateri dari FKIP Universitas Djuanda yaitu Bapak Teguh Prasetyo, M.Pd. dan dari Pusdatin yaitu Ibu Rica Yanuarti, M.Pd. dan Ibu Ita Utari, S.Pd. Pelaksanaan webinar sesi ke II ini dilaksanakan pukul 09.30 sampai pukul 11.00 WIB. Webinar sesi II ini memfasilitasi peserta untuk memahami teknis penggunaan aplikasi Portal Rumah Belajar dalam kegiatan pembelajaran daring di masa pandemi.

i. Pelaksanaan Webinar Sesi III

Webinar pendampingan pembelajaran daring berbasis aplikasi Portal Belajar sesi III ini dilaksanakan pada hari Selasa, 17 November 2020 dengan sub-tema "Optimalisasi Pemanfaatan Fitur Portal Rumah Belajar" yang dibawakan oleh Ibu Rica Yanuarti, M.Pd. dan Ibu Ita Utari, S.Pd. dari Pusdatin serta special remarks disampaikan oleh Ibu Zahra Khusnul Lathifah, M.Pd.I. Webinar sesi III ini memberikan kesempatan kepada para peserta untuk memahami penggunaan fitur utama dan fitur pendukung yang tersedia dalam aplikasi Portal Rumah Belajar. Optimalisasi fitur-fitur tersebut dapat mendukung guru dalam mengelola kegiatan pembelajaran daring melalui penggunaan aplikasi Portal Rumah Belajar.

j. Evaluasi

Kegiatan evaluasi ini pada dasarnya terbagi menjadi dua jenis evaluasi pada pelaksanaan pengabdian ini. Evaluasi yang pertama adalah evaluasi dalam bentuk post tes yang diberikan setiap selesai sesi webinar. Adanya post tes tersebut dimaksudkan untuk mengetahui capaian dan keberhasilan tiap sesi webinar. Berdasarkan hasil post tes tersebut selanjutnya dianalisis untuk mendeksirpsikan capaian dan keberhasilan webinar per sesi. Adapun evaluasi yang kedua yakni dilaksanakan setelah seluruh rangkaian kegiatan pengabdian ini selesai. Pada tahap ini tim pengabdian melakukan analisis keberhasilan dan kekurangan dari kegiatan pengabdian yang telah dilaksanakan. Hasil evaluasi tersebut selanjutnya digunakan untuk meningkatkan pelaksanaan pengabdian serupa dikemudian hari.

\section{HASIL DAN PEMBAHASAN}

Pelaksanaan Webinar Nasional dengan tema utama "Pendampingan Pembelajaran Daring berbasis Aplikasi Portal Belajar" menarik peserta sebanyak 301 orang yang merupakan para guru dari berbagai wilayah di Indonesia yaitu Jawa 
Barat, Jawa Tengah, Jawa Timur, Kepulauan Bangka Belitung, Kalimantan Utara, Kalimantan Selatan, Lampung, Sulawesi Utara, Sumatera Selatan, dan Kepulauan Riau. Sebagaimana yang telah dipaparkan sebelumnya bahwa kegiatan webinar ini dilaksanakan dalam tiga sesi yang mengusung sub-tema berbeda pada tiap sesinya. Masing-masing sub-tema antar sesi saling berkaitan satu sama lain dalam mendorong peserta memahami pemanfaatan aplikasi Portal Rumah Belajar dalam praktik pembelajaran daring yang saat ini tengah dilaksanakan. Pada dasarnya teknis pelaksanaan pendampingan pada tiap sesi webinar dilaksanakan dengan pembahasan materi diawal oleh seluruh pemateri kemudian dilanjutkan ke sesi tanya jawab dan terdapat aktivitas evaluasi di mana peserta diajak untuk mengasah pemahamannya mengenai materi yang telah disampaikan oleh para pemateri.

Sebagaimana paparan sebelumnya di atas bahwa kegiatan pendampingan yang direalisasikan melalui webinar nasional ini dilaksanakan dalam tiga sesi secara paralel yakni dari tanggal 3 November 2020 sampai 17 November 2020. Pada tiap sesi mengusung sub-tema berbeda namun tetap berkaitan erat dengan tema utama dan antar sub-tema tersebut saling berkaitan. Desain rangkaian sesi dengan sub-tema tersebut memfasilitasi para peserta untuk memahami urgensi dan optimalisasi Portal Rumah Belajar dalam pembelajaran daring di masa pandemi baik dalam tataran teoritis maupun teknis. Berikut akan diuraikan lebih lanjut hasil kegiatan pada masing-masing webinar.

Webinar sesi I dilaksanakan pada tanggal 3 November 2020 dari pukul 09.30-11.00 WIB dengan sub-tema mengenai "Sosialisasi Pendampingan Belajar Online". Kegiatan tersebut menguraikan peranan penting guru serta orang tua dalam memberikan pendampingan belajar online kepada peserta didik selama BDR. Selain itu ada pula pendalaman materi mengenai kiatkiat melaksanakan pembelajaran daring yang menarik, menyenangkan dan efektif di masa pandemi melalui penggunaan digital tools. Hasil dari kegiatan pendampingan melalui webinar tersebut yakni terjadi peningkatan pemahaman peserta mengenai urgensi pendampingan belajar daring serta bagaimana melaksanakan pengelolaan pembelajaran daring yang efektif. Para peserta yang saat ini tengah melaksanakan pembelajaran daring pun memperoleh peningkatan pemahaman mengenai trik menciptakan pembelajaran daring yang menyenangkan serta kemampuan pemecahan masalah pada pembelajaran daring yang tengah mereka laksanakan. Capaian pelaksanaan webinar sesi I tersebut berdasarkan hasil post tes yang diikuti oleh para peserta setelah kegiatan webinar selesai. Berikut disajikan persentase capaian peserta pada webinar sesi I:

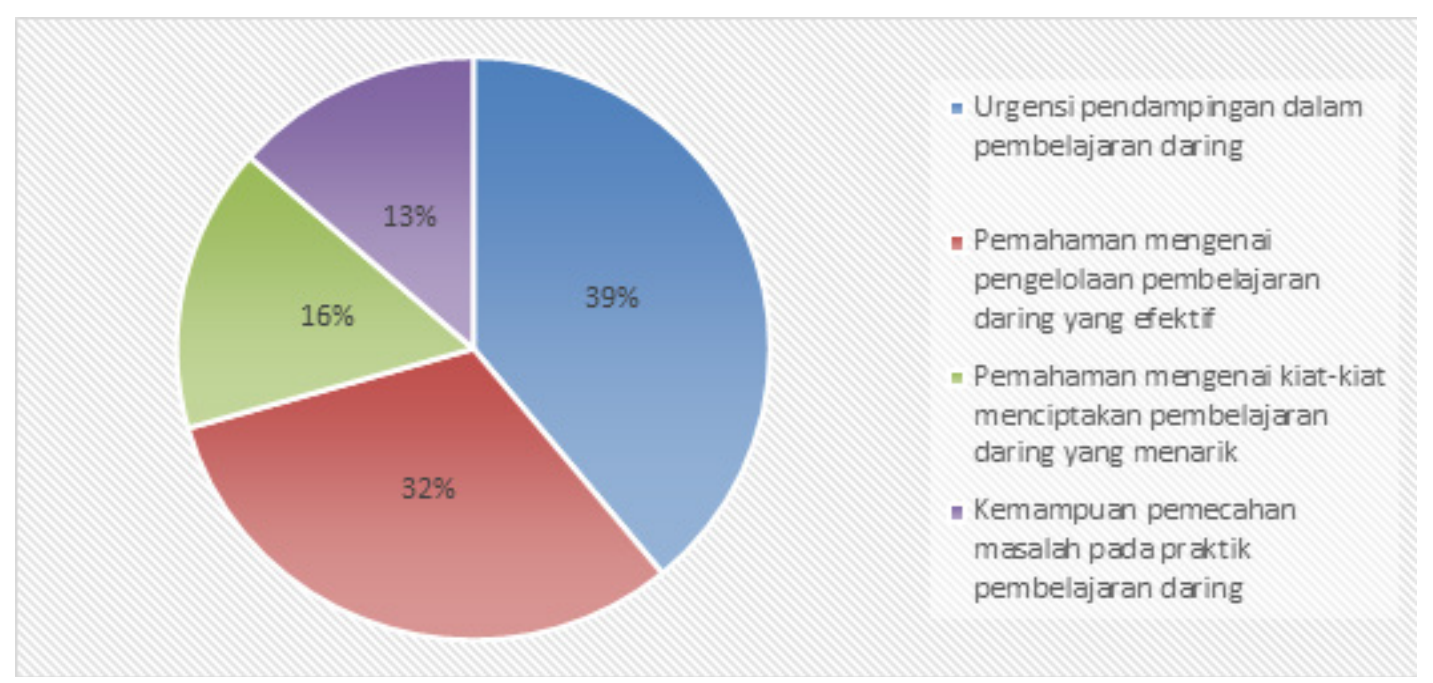

Gambar 4. Diagram Capaian Webinar Sesi I 


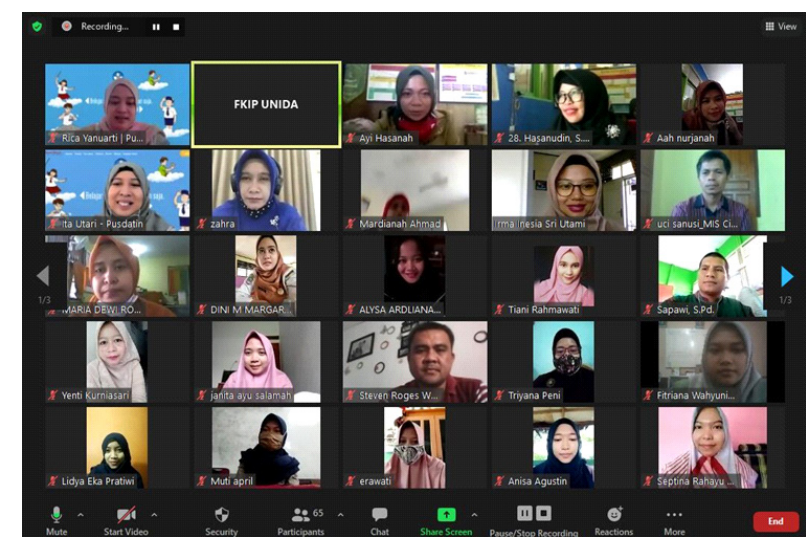

Gambar 5. Pelaksanaan Webinar Sesi I

Berdasar pada diagram pie di atas, dapat diketahui bahwa capaian peserta dengan persentase tertinggi berada pada peningkatan pemahaman mengenai urgensi pendampingan dalam pembelajaran daring yakni sebesar $39 \%$, selanjutnya peningkatan pengelolaan pembelajaran daring secara efektif sebesar $32 \%$, kemudian peningkatan pemahaman mengenai kiat-kiat menciptakan pembelajaran daring yang menarik sebesar $16 \%$, dan peningkatan kemampuan pemecahan masalah pembelajaran daring sebesar $13 \%$.

Webinar sesi II dilaksanakan pada tanggal 10 November 2020, webinar sesi kedua ini mengusung sub tema "Bimbingan Teknis Aplikasi Portal Rumah Belajar". Webinar sesi kedua ini memberikan pengalaman langsung kepada peserta untuk mengenal aplikasi Portal Rumah Belajar Kemdikbud. Melalui paparan pemateri, peserta dituntun untuk memahami penggunaan aplikasi Portal Rumah Belajar dan bagaimana mengaplikasikannya dalam kegiatan mengajar di satuan pendidikan masing-masing. Hasil dari kegiatan webinar sesi kedua ini, peserta memperoleh peningkatan pengetahuan mengenai aplikasi Portal Rumah Belajar, mengenali beragam fitur utama dan fitur pendukung yang ada dalam portal Rumah Belajar, serta terjadi peningkatan mengenai teknis penggunaan aplikasi Portal Rumah Belajar dari tahap proses pendaftaran hingga tahap pengguna aktif yang berperan sebagai admin dan penyelenggara di satuan pendidikan masing-masing. Sebagaimana pada sesi I, data capaian peserta pada kegiatan webinar sesi II diperoleh melalui post tes yang dilaksanakan setelah kegiatan webinar selesai. Persentase capaian peserta pada kegiatan webinar sesi II dapat dilihat pada Gambar 6.

Berdasar pada diagram pada Gambar 6, dapat diketahui bahwa capaian tertinggi pada webinar sesi II yakni ada pada peningkatan pengetahuan peserta webinar mengenai aplikasi Portal Rumah Belajar yakni sebesar $42 \%$ dibanding dengan pemahaman sebelum mengikuti kegiatan webinar tersebut. Adapun selanjutnya terjadi pula peningkatan minat dalam menggunakan Portal Rumah Belajar dalam pembelajaran daring di satuan masingmasing yakni sebesar 27\%. Kemudian terjadi peningkatan pula dalam pemahaman peserta mengenai fitur-fitur yang ada dalam aplikasi Portal Rumah Belajar yakni sebesar 17\% serta peningkatan pemahaman dari penggunaan

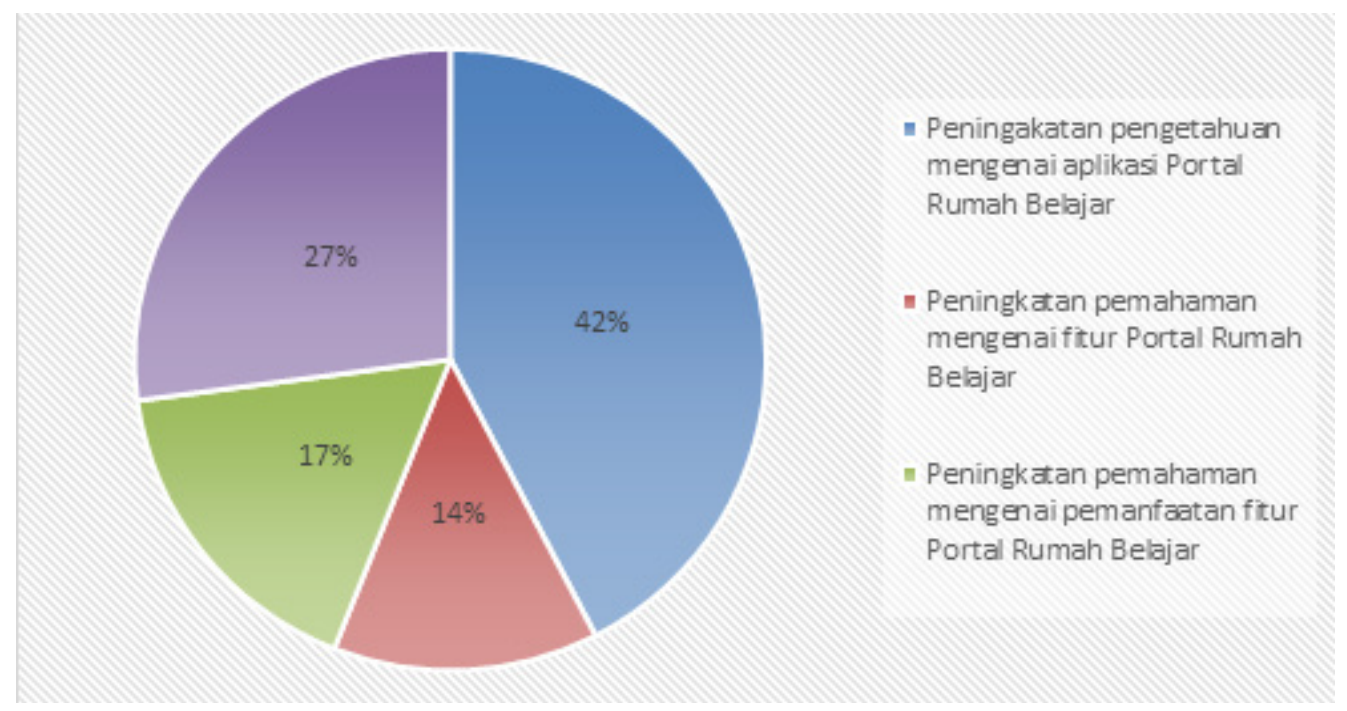

Gambar 6. Diagram Capaian Webinar Sesi II 


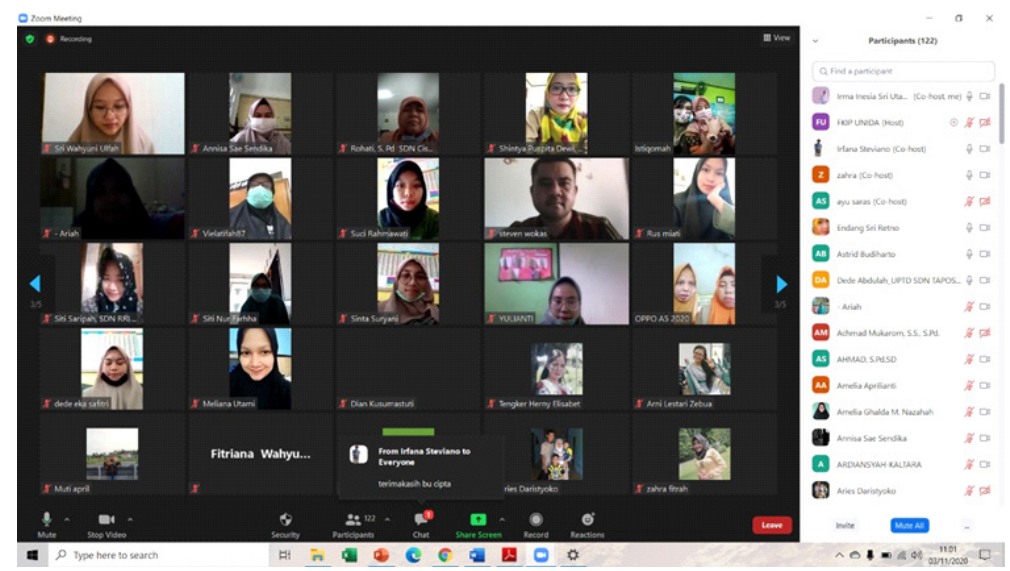

Gambar 7. Pelaksanaan Webinar sesi II

tiap fitur tersebut yakni sebesar 14\%. Capaian tersebut menunjukkan bahwa kegiatan webinar pada sesi II telah berhasil mensosialisasikan Portal Rumah Belajar pada para peserta sehingga muncul peningkatan minat untuk memanfaatkan aplikasi tersebut pada praktik pembelajaran daring. Hal ini pun terlihat dari antusiasme para peserta untuk menjadi user Portal Rumah Belajar sehingga tim ahli Portal Rumah belajar memfasilitasi para peserta untuk mendaftarkan dirinya melalui jaringan brand ambassador Portal Rumah belajar yang ada di wilayah masing-masing.

Kemudian untuk webinar sesi 3 dengan sub tema "Optimalisasi Pemanfaatan Fitur Portal Rumah Belajar" yang dilaksanakan pada tanggal 17 November 2020. Webinar ketiga ini mengupas bagaimana cara mengoptimalkan penggunaan masing-masing fitur yang ada dalam portal Rumah Belajar baik itu berupa fitur utama maupun fitur pendukung. Pengkajian mengenai ragam fitur-fitur tersebut meningkatkan keterampilan para peserta dalam mengoperasikan dan mengelola kegiatan belajar mengajar dengan sistem daring melalui aplikasi tersebut. Hasil dari webinar sesi ketiga ini yaitu peserta memperoleh pemahaman mengenai masing-masing fitur yang tersedia dalam aplikasi Portal Rumah Belajar, memahami bagaimana cara mengoptimalkan masing-masing fitur yang dapat dimanfaatkan untuk melaksanakan dan mengoptimalkan pembelajaran daring, serta memperoleh pemahaman mengenai solusi pemecahan masalah dari hambatan yang muncul dalam penggunaan aplikasi Portal Rumah Belajar pada kegiatan pembelajaran daring. Capaian pada webinar sesi 3 disajikan dalam diagram di bawah ini:

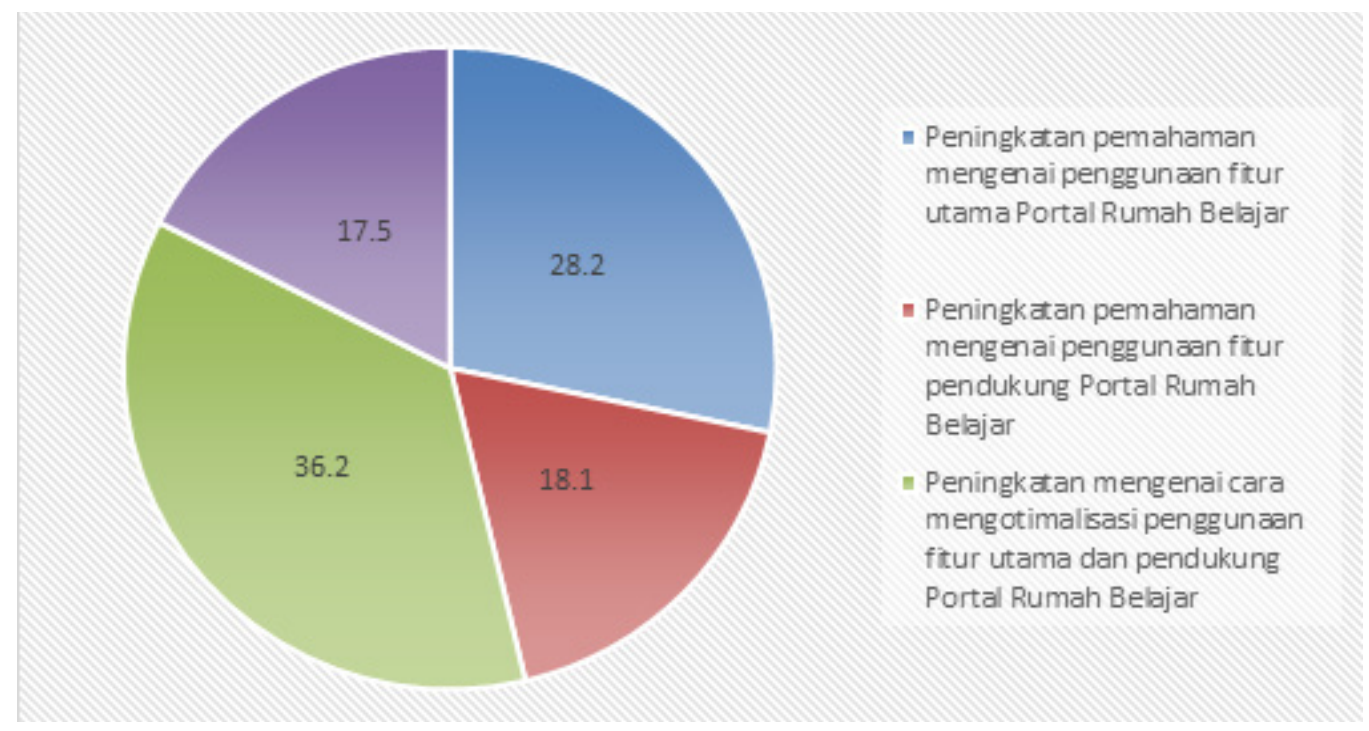

Gambar 8. Diagram Capaian Webinar Sesi 3 
Berdasar pada diagram di atas, dapat diketahui bahwa capaian tertinggi berada pada peningkatan pemahaman peserta mengenai cara mengoptimalkan penggunaan fitur utama dan pendukung aplikasi Portal Rumah Belajar yaitu sebesar 36,2\%, kemudian diikuti peningkatan pemahaman peserta mengenai penggunaan fitur utama Portal Rumah Belajar sebesar 28,2\%, selanjutnya peningkatan pemahaman mengenai penggunaan fitur pendukung Portal Rumah Belajar sebesar 18,1 \% dan terakhir capaian ada pada peningkatan kemampuan pemecahan masalah terkait penggunaan Portal Rumah Belajar yaitu sebesar 17,5\%. Berdasarkan capaian tersebut diketahui bahwa peserta mengalami peningkatan pemahaman mengenai fitur-fitur yang tersedia dalam Portal Rumah Belajar pada praktik pembelajaran daring.

Setelah rangkaian kegiatan webinar selesai, tingkat ketertarikan untuk menggunakan Portal Rumah Belajar meningkat. Persentase ketertarikan menggunakan aplikasi tersebut dapat dilihat pada diagram pada Gambar 9.

Berdasarkan keseluruhan paparan webinar di atas dapat diketahui bahwa melalui rangkaian kegiatan ini menghasilkan peningkatan ketertarikan untuk menggunakan Portal Rumah Belajar, meningkatkan pemahaman dalam mengoperasikan dan mengoptimalkan penggunaan fitur dalam aplikasi Portal Rumah Belajar pada praktik pembelajaran daring. Para peserta yang telah mengikuti seluruh rangkaian webinar ini dapat menjadi pelopor dan penggerak rekan-rekan sejawatnya untuk memanfaatkan aplikasi Portal Rumah Belajar dalam melaksanakan pembelajaran daring yang menarik di satuan pendidikan masing-masing sesuai dengan jenjangnya di masa pandemi saat ini. Hasil evaluasi akhir dari kegiatan pengabdian dalam bentuk pendampingan pembelajaran daring berbasis aplikasi Portal Rumah Belajar ini menunjukkan bahwa kegiatan tersebut dinilai berhasil mensosialisasikan implementasi Portal Rumah Belajar dalam praktik pembelajaran dengan sistem daring di masa pandemi saat ini. Namun pada praktiknya keterbatasan waktu menjadi kendala untuk mendalami penggunaan fitur-fitur dalam aplikasi Portal Rumah Belajar secara keseluruhan. Adapun para peserta webinar menunjukkan minat yang tinggi untuk melaksanakan kegiatan webinar nasional kembali dengan tema utama mengenai pemanfaatan aplikasi berbasis Revolusi Industri 4.0 sebagai platform pendukung pembelajaran daring.

\section{SIMPULAN}

Aplikasi Portal Rumah Belajar sebagai ruang kelas virtual dalam praktik pembelajaran daring saat ini masih kurang diminati oleh para guru yang pada praktiknya lebih banyak memanfaatkan WhatsApp Group. Kondisi tersebut melatarbelakangi pelaksanaan kegiatan pengabdian dalam bentuk webinar nasional yang terbagi dalam tiga sesi. Hasil yang diperoleh dari kegiatan ini yaitu pemahaman serta kesadaran peserta yang didominasi oleh tenaga pendidik mengenai urgensi pendampingan

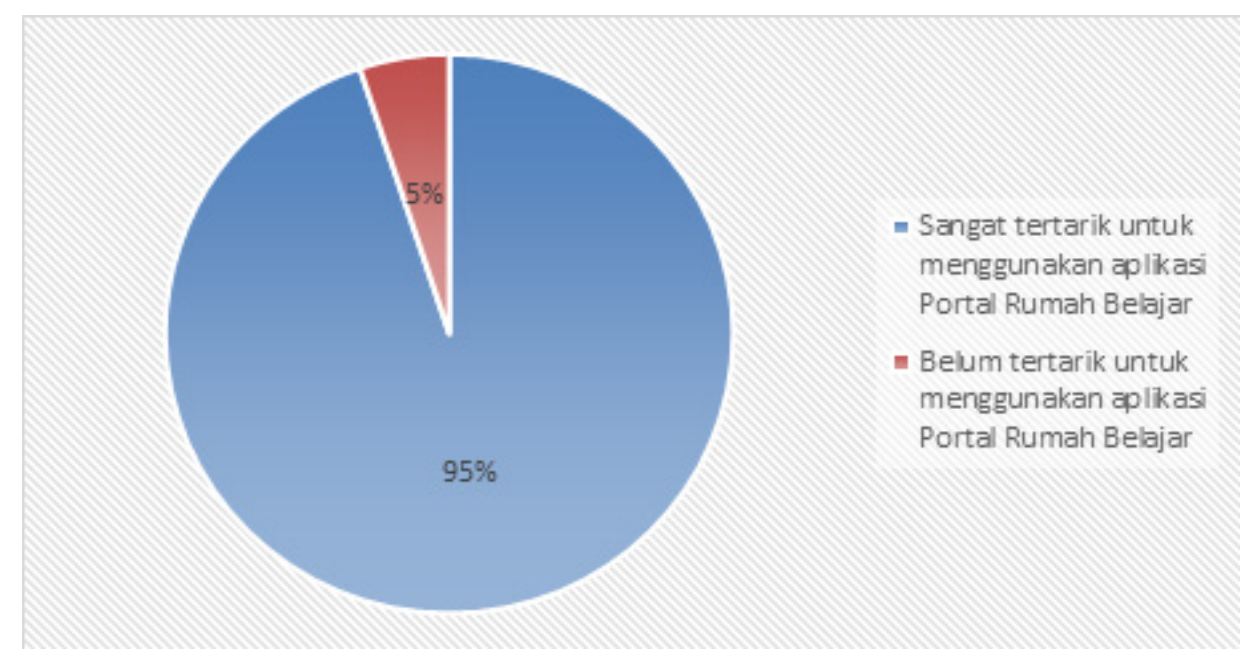

Gambar 9. Grafik Ketertarikan terhadap Portal Rumah Belajar 
dalam kegiatan pembelajaran daring selama masa pandemi cenderung meningkat, kemudian pengetahuan dan pemahaman para peserta mengenai penggunaan aplikasi Portal Rumah Belajar pun menunjukkan peningkatan, selain itu para peserta pun memahami cara mengoptimalkan tiap fitur yang tersedia dalam aplikasi Portal Rumah Belajar dalam kegiatan pembelajaran daring. Tingginya antusiasme peserta untuk menggali lebih jauh mengenai aplikasi Portal Rumah Belajar selama kegiatan pendampingan ini berlangsung menunjukkan bahwa para peserta menyadari potensi Portal Rumah Belajar untuk meningkatkan kualitas belajar mengajar daring yang mereka lakukan di satuan pendidikan masing-masing.

Mempertimbangkan tingginya antusiasme para peserta untuk mendalami aplikasi Portal Rumah Belajar dalam kegiatan pembelajaran daring, maka disarankan untuk selanjutnya mengadakan kegiatan pelatihan mengenai pendalaman aplikasi Portal Rumah Belajar, baik dalam bentuk workshop maupun seminar yang menghadirkan tim ahli aplikasi Portal Rumah
Belajar dari Pusdatin Kemdikbud ke sekolahsekolah untuk meningkatkan sosialisasi dan minat menggunakan aplikasi tersebut dalam pembelajaran jarak jauh. Adapun kegiatan tersebut dapat dipandang sebagai sebuah langkah nyata mendorong sekolah di Indonesia untuk siap meningkatkan efektivitas kegiatan belajar mengajarnya dalam sistem online yang relevan dengan kebutuhan zaman abad ini.

\section{PERSANTUNAN}

Ucapan terima kasih kami sampaikan kepada Lembaga Pengabdian pada Masyarakat Universitas Djuanda dan Fakultas Keguruan dan Ilmu Pendidikan Universitas Djuanda yang telah memberikan bantuan dana bagi terselenggaranya kegiatan pengabdian ini. Kemudian ucapan terima kasih kami sampaikan juga kepada Pusat Data dan Teknologi Informasi Kementerian Pendidikan dan Kebudayaan yang telah berkenan menjalin kerjasama dan berkontribusi pada kegiatan pendampingan pembelajaran daring berbasis aplikasi Portal Rumah Belajar.

\section{REFERENSI}

Assidiqi, M. H., \& Sumarni, W. (2020). Pemanfaatan Platform Digital di Masa Pandemi Covid-19. Seminar Nasional Pascasarjana 2020.

Bhagaskara, A. E., Nur Afifah, E., \& Maulana Putra, E. (2021). Pembelajaran dalam Jaringan (Daring) berbasis WhatsApp di SD Yapita. ZAHRA: Research and Tought Elementary School of Islam Journal, 2(1), 13-23. https://doi.org/10.37812/zahra.v2i1.183

Chabibie, M. H., \& Hakim, W. (2016). Pengaruh Penerimaan Teknologi dengan Kebergunaan Web: Studi Kasus Portal Rumah Belajar Kemendikbud. Jurnal Ilmu Komunikasi Ultimacomm, 8(1).

Daheri, M., Juliana, J., Deriwanto, D., \& Amda, A. D. (2020). Efektifitas WhatsApp sebagai Media Belajar Daring. Jurnal Basicedu, 4(4), 775-783. https://doi.org/10.31004/basicedu.v4i4.445

Ferismayanti. (2019). Studi Kelayakan Pemanfaatan Portal Rumah Belajar untuk Meningkatkan Kwalitas Pembelajaran.

Gegenfurtner, A., Zitt, A., \& Ebner, C. (2020). Evaluating Webinar-Based Training: A Mixed Methods Study of Trainee Reactions Toward Digital Web Conferencing. International Journal of Training and Development, 24(1), 5-21. https://doi.org/10.1111/ijtd.12167

Imania, K. A. N. (2019). Rancangan Pengembangan Instrumen Penilaian Pembelajaran berbasis Daring. Jurnal PETIK, 5.

Lieser, P., Taff, S. D., \& Murphy-Hagan, A. (2018). The Webinar Integration Tool: A Framework for Promoting Active Learning in Blended Environments. Journal of Interactive Media in Education, 2018(1), 7. https://doi.org/10.5334/jime.453 
Putria, H., Maula, L. H., \& Uswatun, D. A. (2020). Analisis Proses Pembelajaran dalam Jaringan (Daring) Masa Pandemi Covid- 19 pada Guru Sekolah Dasar. Jurnal Basicedu, 4(4), 861-870. https://doi. org/10.31004/basicedu.v4i4.460

Rigianti, H. A. (2020). Kendala Pembelajaran Daring Guru Sekolah Dasar di Kabupaten Banjarnegara. Elementary School, 7(2).

Salsabila, U. H., Lestari, W. M., Habibah, R., Andaresta, O., \& Yulianingsih, D. (2020). Pemanfaatan Teknologi Media Pembelajaran di Masa Pandemi Covid-19. Trapsila: Jurnal Pendidikan Dasar, $2(3)$.

Saragih, E. M., \& Ansi, R. Y. (2020). Efektivitas Penggunaan WhatsApp Group selama Pandemi COVID-19 bagi Pelaku Pendidik. Sinergi Hasil Penelitian Dalam Menghasilkan Inovasi Di Era Revolusi 4.0, 207-212.

Sofyana, \& Abdul. (2019). Pembelajaran Daring Kombinasi Berbasis Whatsapp pada Kelas Karyawan Prodi Teknik Informatika Universitas PGRI Madiun. Jurnal Nasional Pendidikan Teknik Informatika, 8(1).

Sulistiyani, Y. (2018). Dinamika Pendidikan dan Pembelajaran Abad XXI. Kemendikbud. http://pena. belajar.kemdikbud.go.id/2018/07/dinamika-pendidikan-dan-pembelajaran-abad-xxi/

Supandri. (2018). Faktor-Faktor Penyebab Guru Belum Optimal Memanfaatkan Portal Rumah Belajar dalam Kegiatan Pembelajaran. Jurnal Teknodik, 22(1).

Warsita, B. (2019). Pemanfaatan Portal Rumah Belajar untuk Meningkatkan Kualitas Pembelajaran. Jurnal Teknodik, 23(1).

Yanti, M. T., Kuntarto, E., \& Kurniawan, A. R. (2020). Pemanfaatan Portal Rumah Belajar Kemendikbud sebagai Model Pembelajaran Daring di Sekolah Dasar. ADI WIDYA: Jurnal Pendidikan Dasar, 5(1). 